ISSN 0258-7122

Bangladesh J. Agril. Res. 37(4): 559-571, December 2012

\title{
EVALUATION OF DRILL SEEDING PATTERNS AND NITROGEN MANAGEMENT STRATEGIES FOR WET AND DRY LAND RICE
}

\author{
M. AKKAS ALI ${ }^{1 *}$, J. K. LADHA ${ }^{2}$, J. RICKMAN ${ }^{3}$ \\ J. S. LALES ${ }^{4}$ AND M. MURSHEDUL ALAM ${ }^{5}$
}

\begin{abstract}
Many Asian farmers are shifting from rice transplanting to direct seeding because the latter requires less labour, time, drudgery, and cultivation cost. Direct seeding is usually practiced in either wet or dry land preparation depending on water availability. The present study aimed at evaluating the potential of single and paired rows drill seeding patterns and five $\mathrm{N}$ management strategies on crop productivity, $\mathrm{N}$ use-efficiency, and apparent $\mathrm{N}$ balance. The experiment was laid out in a split plot design with two seeding patterns as main plots and five $\mathrm{N}$ treatments as subplots with three replications. Drill seeding did not affect grain yield, water, and $\mathrm{N}$ use-efficiencies and $\mathrm{N}$ balance. Grain yield increased with LCC-based N management with the lower $\mathrm{N}$ fertilizer input. Soil available $\mathrm{N}$ after 2 years of rice cropping was similar to the amount at the beginning indicating most of applied fertilizer $\mathrm{N}$ was lost.
\end{abstract}

Keywords: Drill seeding, planting pattern, $\mathrm{N}$-use efficiency, and $\mathrm{N}$ balance.

\section{Introduction}

Many Asian farmers are shifting rice establishment method from transplanting in puddle soil to direct seeding in either puddle soil or dry soil after dry tillage because the latter requires less labour, time, drudgery and cultivation cost (Bhushan et al., 2007; Pandey and Velasco, 2002; Yamauchi et al., 2000). Direct seeding requires only $34 \%$ of the total labour requirement of transplanted rice (Ho Nai-Kin and Romli 2002) and 29\% of the total cost of transplanted rice production without any yield loss. Farmers usually practice direct seeding of rice by broadcast method. It can also be done by drilling the seeds in line either manually or with the use of drill machine by sowing in line either manually or with the use of simple plastic made implement known as drum seeder (Balasubramanian et al., 2003). Drill seeding, a variant of direct seeding, is

\footnotetext{
${ }^{1}$ Hub Manager, CSISA (IRRI-CIMMYT) Project, Regional BSRI Campus, CERDI Road, Joydebpur, Gazipur 1701, Bangladesh, alim.akkas@yahoo.com, 2IRRI Representative, IRRI India Office, International Rice Research Institute (IRRI), CG Block, NASC Complex Dev Prakash Sastri Marg, Pusa, New Delhi 110012, India, Jkladha@cgiar.org. ${ }^{3}$ Ex-Head, Agricultural Engineering Division, IRRI, DAPO Box 7777, Metro Manila, Philippines, ${ }^{4}$ Professor, Dept. of Agronomy, University of the Philippines Los Baños, Laguna, Philippines., ${ }^{5}$ Research Platform Coordinator, CSISA Project, IRRI, BRRI Campus, Bangladesh, m.alam@irri.org; *Corresponding author (alim.akkas@yaho.com)
} 
sowing the seeds in rows at specified seed rate, depth, and covers those with soil under dry or moist condition. This method of rice establishment substantially reduces labour requirement, improves emergence of seeds, and reduces lodging to less than 10\% (Bakker et al., 2002). Combined with fertilizer application and effective control of weeds through the use of herbicides and mechanical weeder, drill-seeding can increase grain yield by $25 \%$ (Devnani, 2002). The benefit of direct-seeding of rice and development of mechanical device or power operated machineries for tillage and seeding purposes have created an opportunity to use different planting methods of crop establishment in direct-seeded rice cultivation. Single-row drill-seeder, both manual and mechanical, is traditionally used for direct seeding cultivation.

Nitrogen fertilizer management in emerging direct-seeded rice cultivation is important and a challenging task to achieve high yield and increased $\mathrm{N}$ use efficiency (NUE). In general, $\mathrm{N}$ uptake is less than $40 \%$ of the total $\mathrm{N}$ applied in rice cultivation (Ladha et al., 2005). The low level of $\mathrm{N}$ utilization is due to high $\mathrm{N}$ losses through volatilization, denitrification, runoff, and leaching. Application of $\mathrm{N}$ not synchronized with plant need leads to high $\mathrm{N}$ losses, low yield, and poor grain quality. Nitrogen uptake patterns over the growing season depend on the availability of soil $\mathrm{N}$, timing of fertilizer application, and amount of fertilizer $\mathrm{N}$ available (Ladha et al., 2005).

Crop demand and $\mathrm{N}$ supply should be synchronized taking into the account of effective indigenous $\mathrm{N}$ supply, and crop uptake under consideration to increase $\mathrm{N}$ fertilizer use efficiency. Crop demand for $\mathrm{N}$ can be predicted by plant-based $\mathrm{N}$ management strategies, which requires thorough monitoring of the $\mathrm{N}$ status of the rice crop at different growth stages. In recent years, Leaf Colour Chart (LCC) has become an effective tool to estimate leaf $\mathrm{N}$ status - an indicator of plant $\mathrm{N}$ demand (Ladha et al., 2005)

Information on NUE and $\mathrm{N}$ balance under intermittent irrigation management approach are imperative in making sound fertilizer recommendations that reduce $\mathrm{N}$ losses and maintain potential yield of direct-seeded rice. Research findings on NUE and $\mathrm{N}$ balance in paired and single-row planting methods in drill-seeded rice are, however, meager. This paper presents the results of a field study conducted to evaluate the potential of single and paired row drill seeding patterns and five $\mathrm{N}$ management strategies on crop productivity, $\mathrm{N}$ use-efficiency, and apparent $\mathrm{N}$ balance.

\section{Materials and Method}

\section{Experimental site}

A field experiment was conducted at the experimental farm of the International Rice Research Institute (IRRI), Los Baños, Laguna, Philippines during the wet 
season (WS) of 2003 (June-October) and the dry season (DS) of 2004 (JanuaryMay). Geographically, the site is located within a major irrigated rice production area at $14^{\circ} 11 \mathrm{~N}$ latitude and $121^{\circ} 15^{\prime} \mathrm{E}$ longitude. The textural class of the soil is clay and taxonomically classified as an Andaqueptic Haplaquoll (USDA Soil Taxonomy) with a bulk density $0.92 \mathrm{~g} \mathrm{~cm}^{-3}$ in the first $60 \mathrm{~cm}$ soil depth. The soil had a $6.43 \mathrm{pH}$, total N $1.6 \mathrm{~g} / \mathrm{kg}$, organic C $19.3 \mathrm{~g} / \mathrm{kg}$, Olsen P $6.63 \mathrm{mg} / \mathrm{kg}$, and available K $8.2 \mathrm{meq} / \mathrm{kg}$. Available $\mathrm{Zn}$ content was $0.51 \mathrm{mg} / \mathrm{kg}$, while cation exchange capacity was $31 \mathrm{meq} / 100 \mathrm{~g}$. The total rainfall from June 2003 to May 2004 was $1397 \mathrm{~mm}$ about 78\% of which occurred from June to November. Mean maximum and minimum temperatures were 31.4 and $24.4{ }^{\circ} \mathrm{C}$ during the wet season (June to October, 2003) and 30.9 and $23.6{ }^{\circ} \mathrm{C}$ during the dry season (January to May, 2004), respectively.

\section{Experimental design and treatments}

The experiment was laid out in a split-plot design with two drill seeding patterns as main plots $\left(\mathrm{S}_{1}\right.$ and $\left.\mathrm{S}_{2}\right)$ and $5 \mathrm{~N}$ management strategies as subplots $\left(\mathrm{N}_{1}\right.$ to $\left.\mathrm{N}_{5}\right)$ with three replications. The unit plot size was $220 \mathrm{~m}^{2}(20 \mathrm{~m} \times 11 \mathrm{~m})$ surrounded by bunds, and canals were made in between two bunds for irrigation and drainage. An IRRI seed drill attached with a 12 rows seeder mounted tractor was used for sowing. The details of main plot and sub plot treatments are as follows:

Single row seeding $\left(\boldsymbol{S}_{1}\right)$ : Dry seeds at $65 \mathrm{~kg} / \mathrm{ha}$ were drilled in rows at $20 \mathrm{~cm}$ spacing and covered with soil.

Paired rows seeding $\left(\boldsymbol{S}_{2}\right)$ : Dry seeds at $65 \mathrm{~kg} / \mathrm{ha}$ were drilled with a drill machine in paired rows at $10-\mathrm{cm}$ spacing between rows and $30-\mathrm{cm}$ spacing between pair of rows and covered with soil.

$N$ treatment $1\left(N_{1}\right)$ : No fertilizer $\mathrm{N}$ applied.

$N$ treatment $2\left(N_{2}\right)$ : Prilled urea at $120 \mathrm{~kg} \mathrm{~N} / \mathrm{ha}$ in the wet season and $150 \mathrm{~kg}$ $\mathrm{N} / \mathrm{ha}$ in dry season was broadcast in three splits - 30\% each at planting and maximum tillering stage, and $40 \%$ at panicle initiation stage,

$N$ treatment $3\left(N_{3}\right)$ : Leaf colour chart (LCC)-based nitrogen application-Pilled urea was broadcast using a LCC reading (Balasubramanian et al., 2002). The leaf colour of fully expanded youngest leaf of each of 10 selected healthy hills were measured by LCC at 7-10 d intervals starting $25 \mathrm{~d}$ after sowing (DAS) till flowering stage ( $10 \%$ plants flower). If the leaf colour fell between two colour strips of LCC, than the mean of the two colour strip numbers was taken as the LCC reading. The critical LCC value for drill-seeded rice was 3 and 3.5 during the wet and dry seasons, respectively. Whenever the average of $10 \mathrm{LCC}$ readings fell below the critical value fertilizer $\mathrm{N}$ at $23 \mathrm{~kg} / \mathrm{ha}$ and $30 \mathrm{~kg} / \mathrm{ha}$ was applied during the wet and dry seasons, respectively. 
$N$ treatment $4\left(N_{4}\right)$ : Prilled urea at $120 \mathrm{~kg} \mathrm{~N} / \mathrm{ha}$ in wet and $150 \mathrm{~kg} \mathrm{~N} / \mathrm{ha}$ in dry season broadcast in two splits - $40 \%$ at 10 days after emergence (DAE) and $60 \%$ at panicle initiation (PI) stage.

$N$ treatment $5\left(N_{5}\right)$ : Prilled urea at $120 \mathrm{~kg} \mathrm{~N} / \mathrm{ha}$ in wet season and $150 \mathrm{~kg} \mathrm{~N} / \mathrm{ha}$ in dry season was broadcast in two splits - $80 \%$ deep placed at planting, and the $20 \%$ applied based on LCC reading.

\section{Field and crop management}

Soils were ploughed under dry conditions. The quantity of crop residue that ploughed down in wet season was not determined. Drill seeding (var. IR73885) was done on 4 July 2003 for the wet season and 7 Feb. 2004 dry season. Plants were thinned at 15 DAS to get a uniform plant stand. Phosphorus as solophos and zinc as $\mathrm{ZnSO}_{4}$ were applied in all plots at $40 \mathrm{~kg} / \mathrm{ha}$ and $10 \mathrm{~kg} / \mathrm{ha}$, respectively, during final harrowing. Potassium as $\mathrm{KCl}$ was likewise applied at $40 \mathrm{~kg} / \mathrm{ha}$ in two equal splits (50\% at planting and 50\% at PI). Standing water was drained at $10 \mathrm{~d}$ after sowing in order to facilitate seed germination and seedling establishment. Irrigation was done whenever soil moisture tension at $15-\mathrm{cm}$ depth reached 0 KPa starting from 15 DAS and continued until $15-\mathrm{d}$ before harvesting. The depth of water applied was measured using a flow meter and maintained $5 \mathrm{~cm}$ at each irrigation. Weeding was done three times by hand weeding and by applying postemergence herbicide. Other plant protection measures were carried out as and when required. Crops were harvested at maturity during 25-26 October 2003 and 27-28 May 2004 in wet and dry seasons, respectively.

\section{Plant, soil and water sampling, and analysis}

Grain and straw yields were obtained from $12 \mathrm{~m}^{2}$ sampling quadrate per plot located approximately $2 \mathrm{~m}$ from the border. Grain yield was reported at $0.14 \mathrm{~g}$ $\mathrm{H}_{2} \mathrm{O} / \mathrm{g}$ fresh weight. Rice plants from four $0.12 \mathrm{~m}^{2}$ one from each of the four sides of grain harvest area were collected at ground level for measuring yield component. Grain and straw sub-samples were dried at $70{ }^{\circ} \mathrm{C}$ for 2 days and then finely ground to pass through a $0.5 \mathrm{~mm}$ sieve. Nitrogen content in the subsamples was determined separately by digesting with concentrated $\mathrm{H}_{2} \mathrm{SO}_{4}$, followed by analysis for total $\mathrm{N}$ by micro-Kjeldahl method (Yoshida, 1976).

Composite soil samples from three spots in each plot at 0-20, 20-40, and 40$60-\mathrm{cm}$ depth were collected using a $5 \mathrm{~cm}$ diameter core sampler before planting and after harvesting of crop. Soil from a plot at each depth was mixed, placed in an icebox, transported to the laboratory, and stored in a freezer till soil extracted with $2 \mathrm{~N} \mathrm{KCl}$ to inhibit $\mathrm{N}$ transformation processes. Ammonium- and nitrate-N were extracted with $2 \mathrm{~N} \mathrm{KCl}$. Ammonium-N in the KCL extract was determined with the salicylate method (Keeney and Nelson, 1982; Kempers, 1986), while nitrate- $\mathrm{N}$ was measured using the copperized $\mathrm{Cd}$ reduction method (Dorich and 
Nelson, 1984; Keeney and Nelson, 1982). The light absorbance of the solutions was determined at a wavelength of $540 \mathrm{~nm}$ (Jackson et al., 1975). Soil moisture content was determined gravimetrically. Concurrently, samples were collected for bulk density determination. Total $\mathrm{N}$, total $\mathrm{C}$, available $\mathrm{P}, \mathrm{K}$, and $\mathrm{Zn}$ were analyzed in a $200 \mathrm{~g}$ sub-sample from a composite sample collected at $0-20 \mathrm{~cm}$ depth before planting and after harvesting.

Water samples from different irrigation channels were collected at maximum tillering, flowering, and harvesting stages of crop growth in both seasons for the determination of $\mathrm{NH}_{4}^{+}-\mathrm{N}$ and $\mathrm{NO}_{3}^{-}-\mathrm{N}$. A composite water sample was stored in an airtight bottle in a freezer until analysis.

\section{Data analysis}

$\mathrm{N}$-use efficiency was expressed as (a) agronomic N-use efficiency $\left(\mathrm{AE}_{\mathrm{N}}\right),(\mathrm{b})$ recovery $\mathrm{N}$-use efficiency $\left(\mathrm{RE}_{\mathrm{N}}\right)$, (c) physiological $\mathrm{N}$-use efficiency $\left(\mathrm{PE}_{\mathrm{N}}\right)$, and (d) partial factor productivity of $\mathrm{N}\left(\mathrm{PFP}_{\mathrm{N}}\right)$ as described by Ladha et al. (2005).

The amount of water applied was measured by an axial flow meter. Wateruse efficiency was calculated as the ratio of yield $(\mathrm{kg} / \mathrm{ha})$ to total water applied (TWU) ( $\mathrm{mm} / \mathrm{ha}$ ) and expressed in $\mathrm{kg} / \mathrm{mm}$.

The data were statistically analyzed by analysis of variance (ANOVA) and the comparison of treatment means was made by least significant difference (LSD) following by IRRISTAT 5.0 programme (IRRI, 2005).

\section{Results and Discussion}

\section{Grain yield and yield-contributing parameters}

Grain yields were not significantly different between single row $(4761 \mathrm{~kg} / \mathrm{ha})$ and paired row $(4529 \mathrm{~kg} / \mathrm{ha})$ in both the seasons and likewise yield parameters remained unchanged.

Changing row spacing by keeping same number of plants per unit area to modify the diurnal exposure of individual plants to the various elements of the microclimate did not provide significant benefit to grain yield.

Nitrogen management significantly influenced grain yield and yield components during both seasons (Table 1). In wet season, $\mathrm{N}_{2}, \mathrm{~N}_{3}, \mathrm{~N}_{4}$, and $\mathrm{N}_{5}$ had similar yields and yield parameters, which were significantly higher from no $\mathrm{N}$ fertilization $\left(\mathrm{N}_{1}\right)$. This implies that various $\mathrm{N}$ timings and LCC aided $\mathrm{N}$ management were not crucial in the wet season. However, the results indicated the possibility of reducing $\mathrm{N}$ input with no yield loss by synchronizing time of application with leaf $\mathrm{N}$ status using the LCC.

During dry season, the LCC based $\mathrm{N}$ management $\left(\mathrm{N}_{3}\right)$ had the highest yield of $5956 \mathrm{~kg} /$ ha followed by $\mathrm{N}_{2}, \mathrm{~N}_{5}, \mathrm{~N}_{4}$, and $\mathrm{N}_{1}$. The differences between $\mathrm{N}_{3}, \mathrm{~N}_{4}$, 
and $\mathrm{N}_{1}$ were significant (Table 1). Similar trend was also observed in case of yield components. These results implies that better synchrony between $\mathrm{N}$ application and plant demand is important in dry season for obtaining higher yield, which could be achieved with the use of LCC. Results also show that $\mathrm{N}_{2}$ and $\mathrm{N}_{5}$ were superior to $\mathrm{N}_{4}$ treatment. More sterility in case of $\mathrm{N}_{4}$ indicated that plants might have suffered with $\mathrm{N}$ deficiency at later growth stages. Buresh et al. (2001) compared various $\mathrm{N}$ management techniques for rice and obtained the highest yield when $\mathrm{N}$ was applied following LCC method. This study also suggested that a lower $\mathrm{N}$ dose at an early stage of growth (without basal) and a higher dose at later stage were effective. Linwattana (2001) reported that yield and agronomic parameters of direct-seeded rice gave better response to $\mathrm{N}$ application when $60 \mathrm{~kg} / \mathrm{haN}$ was applied in three splits $-15 \mathrm{~kg}$ each at 15 and 30 days after emergence (DAE) and the remaining $30 \mathrm{~kg}$ at 45 DAE or at PI. These observations tend to indicate that $\mathrm{N}$ is critically needed possibly between active tillering and panicle initiation.

\section{Water input and water-use efficiency}

Drill-seeding pattern did not influence the amount of irrigation water applied and water-use efficiency (WUE) during both seasons (data not shown). The amount of water applied during wet season was 287 and $325 \mathrm{~mm} /$ ha for single row and paired rows seeding method, respectively. These amounts were about threefold lower than the amount applied in the dry season. The results likewise indicated that changing seeding pattern from the usual single-row drill seeding to pairedrow drill seeding may not increase crop water requirement provided the seeding rate remains unchanged.

\section{Nitrogen-use efficiency}

Drill seeding pattern did not influence any of the $\mathrm{N}$ efficiency parameters $\left(\mathrm{AE}_{\mathrm{N}}\right.$, $\mathrm{RE}_{\mathrm{N}}, \mathrm{PE}_{\mathrm{N}}$, and $\left.\mathrm{PP}_{\mathrm{N}}\right)$. However, $\mathrm{N}$ management strategies and interaction effect of drill seeding pattern and $\mathrm{N}$ management significantly affected all $\mathrm{N}$-use efficiency parameters in both seasons. During wet season, $\mathrm{AE}_{\mathrm{N}}$ was the highest in case of LCC based $\mathrm{N}$ management $\left(\mathrm{N}_{3}\right)$ strategy and was similar with that of $\mathrm{N}_{2}$ strategy (Table 2). During dry season, $\mathrm{N}_{3}$ had the highest $\mathrm{AE}_{\mathrm{N}}$, which was significantly higher than $\mathrm{N}_{2}, \mathrm{~N}_{4}$, and $\mathrm{N}_{5}$. The results indicated that irrespective of seeding pattern, higher $\mathrm{N}$-use efficiency can be achieved through proper synchronization of the time of $\mathrm{N}$ fertilizer application and plant $\mathrm{N}$ demand using leaf colour. The interaction effects of seeding pattern and $\mathrm{N}$ management strategies on $\mathrm{RE}_{\mathrm{N}}$ and $\mathrm{PE}_{\mathrm{N}}$ during wet season are shown in Table 3. The $\mathrm{RE}_{\mathrm{N}}$ in $\mathrm{N}_{3}$ management strategy with paired-row drill-seeding was significantly higher than those in other $\mathrm{N}$ management strategies with both single-row and paired-row seeding patterns. Similarly, the lowest $\mathrm{RE}_{\mathrm{N}}$ was found in $\mathrm{N}_{5}$ management strategy with paired-row seeding pattern. The $\mathrm{RE}_{\mathrm{N}}$ in other $\mathrm{N}$ management strategies did not vary significantly irrespective of drill-seeding patterns. 
Table 1. Effect of nitrogen management strategies on yield and yield contributing parameters during the wet season and dry season.

\begin{tabular}{|c|c|c|c|c|c|c|c|c|c|c|c|c|c|c|}
\hline \multirow{2}{*}{$\begin{array}{l}\text { Nitrogen management } \\
\text { strategy }\end{array}$} & \multicolumn{7}{|c|}{ Wet season 2003} & \multicolumn{7}{|c|}{ Dry season 2004} \\
\hline & $\begin{array}{l}\text { Grain } \\
\text { yield } \\
\text { (kg/ha) }\end{array}$ & $\mid \begin{array}{c}\text { Number of } \\
\text { panicles/ } \\
\mathrm{m}^{2}\end{array}$ & $\begin{array}{c}\text { Number of } \\
\text { filled } \\
\text { spikelets/ } \\
\text { panicle }^{-1}\end{array}$ & $\begin{array}{c}\text { Number } \\
\text { of grains } \\
\text { per square } \\
\text { meter }\end{array}$ & $\begin{array}{c}\text { Plant } \\
\text { height } \\
(\mathrm{cm})\end{array}$ & $\begin{array}{l}\text { Panicle } \\
\text { length } \\
\text { (cm) }\end{array}$ & $\begin{array}{c}1000- \\
\text { grain } \\
\text { wt } \\
(\mathrm{g})\end{array}$ & $\begin{array}{l}\text { Grain } \\
\text { yield } \\
(\mathrm{kg} / \mathrm{ha})\end{array}$ & $\begin{array}{c}\text { Number of } \\
\text { panicles } \\
\text { per square } \\
\text { meter }\end{array}$ & $\begin{array}{c}\text { Number } \\
\text { of filled } \\
\text { spikelets } \\
\text { p panicle- } \\
1\end{array}$ & $\begin{array}{c}\text { Number of } \\
\text { grains } / \mathrm{m}^{2}\end{array}$ & $\begin{array}{c}\text { Plant } \\
\text { height } \\
(\mathrm{cm})\end{array}$ & $\begin{array}{c}\text { Panicle } \\
\text { length } \\
(\mathrm{cm})\end{array}$ & $\begin{array}{c}1000- \\
\text { grain } \\
\text { wt } \\
(\mathrm{g})\end{array}$ \\
\hline No nitrogen $\left(\mathrm{N}_{1}\right)$ & 2667 & 283 & 40 & 10991 & 86 & 24 & 22.99 & 3512 & 536 & 31 & 16877 & 72 & 20.3 & 23.6 \\
\hline $\begin{array}{l}\text { Standard rate with } 3 \\
\text { splits }\left(\mathrm{N}_{2}\right)\end{array}$ & 4966 & 404 & 52 & 21029 & 103 & 25 & 23.39 & 5275 & 694 & 34 & 23654 & 83 & 22.2 & 24.7 \\
\hline $\begin{array}{l}\text { LCC- based } \mathrm{N} \\
\text { management }\left(\mathrm{N}_{3}\right)\end{array}$ & 4709 & 362 & 56 & 20228 & 102 & 25 & 23.31 & 5956 & 674 & 37 & 24870 & 85 & 22.9 & 25.4 \\
\hline $\begin{array}{l}\text { Standard rate with } 2 \\
\text { splits }\left(\mathrm{N}_{4}\right)\end{array}$ & 4565 & 412 & 49 & 20114 & 102 & 26 & 23.30 & 5027 & 761 & 27 & 20529 & 78 & 21.5 & 23.9 \\
\hline $\begin{array}{l}\text { Standard rate with } \\
\text { deep placement \& LCC } \\
\text { based }\left(\mathrm{N}_{5}\right)\end{array}$ & 4507 & 359 & 50 & 17921 & 99 & 25 & 23.92 & 5264 & 646 & 33 & 22259 & 81 & 21.2 & 24.2 \\
\hline CV (\%) & 8.8 & 11.9 & 13.8 & 12.4 & 3.4 & 3.1 & 1.3 & 8.9 & 5.5 & 6.3 & 7.4 & 4.1 & 4.0 & 1.3 \\
\hline LSD & $635^{* *}$ & $73 * *$ & $8^{*}$ & $3781^{* *}$ & $5.6^{* *}$ & $1.3^{* *}$ & $0.50 * *$ & $749.1^{* *}$ & $61.1^{* *}$ & $3.5^{* *}$ & $2706^{* *}$ & $5.5^{* *}$ & $1.5^{* *}$ & $0.5^{* *}$ \\
\hline
\end{tabular}

$\underline{\mathrm{a} /} * *=$ significant at $1 \%$ level, ns $=$ not significant at $5 \%$ level. 
The highest $\mathrm{PE}_{\mathrm{N}}$ was found in the $\mathrm{N}_{3}$ with single-row seeding pattern, which was similar in $\mathrm{N}_{5}$ in both seeding but significantly higher than all other $\mathrm{N}$ management strategies irrespective of seeding pattern (Table 3). These observations suggest prospects for improving N-use efficiency in drill-seeded rice through cultural manipulations that will lead to a more favourable crop micro-environment and higher productivity.

Table 2. Nitrogen-use efficiency as affected by $\mathbf{N}$ management during the wet and dry seasons.

\begin{tabular}{|c|c|c|c|c|}
\hline $\begin{array}{l}\text { Nitrogen management } \\
\text { strategy }\end{array}$ & \begin{tabular}{|c|} 
Agronomic \\
efficiency \\
$(\Delta \mathrm{kg}$ grain $/$ \\
$\mathrm{kg} \mathrm{N}$ \\
applied $)$
\end{tabular} & $\begin{array}{c}\text { Recovery } \\
\text { efficiency } \\
(\Delta \mathrm{kg} \mathrm{N} \\
\text { uptake/kg } \\
\mathrm{N} \text { applied })\end{array}$ & $\begin{array}{c}\text { Physiological } \\
\text { efficiency } \\
(\Delta \mathrm{kg} \text { grain } \\
\Delta \mathrm{kg}^{-1} \mathrm{~N} \\
\text { uptake) }\end{array}$ & $\begin{array}{l}\text { Partial factor } \\
\text { productivity } \\
\text { (kg grain/ } \\
\mathrm{kg} \mathrm{N} \text { applied) }\end{array}$ \\
\hline \multicolumn{5}{|c|}{ Wet season 2003} \\
\hline No nitrogen $\left(\mathrm{N}_{1}\right)$ & - & - & - & - \\
\hline Standard rate with 3 splits $\left(\mathrm{N}_{2}\right)$ & 19 & 0.35 & 56 & 41 \\
\hline LCC- based $\mathrm{N}$ management $\left(\mathrm{N}_{3}\right)$ & 22 & 0.37 & 61 & 51 \\
\hline Standard rate with 2 splits $\left(\mathrm{N}_{4}\right)$ & 16 & 0.31 & 52 & 38 \\
\hline $\begin{array}{l}\text { Standard rate with deep placement \& } \\
\text { LCC based }\left(\mathrm{N}_{5}\right)\end{array}$ & 15 & 0.24 & 65 & 38 \\
\hline $\mathrm{CV}(\%)$ & 16 & 19 & 11 & 7 \\
\hline LSD & $4.9^{* *}$ & $0.07 *$ & $7.5^{*}$ & $4.8^{* *}$ \\
\hline \multicolumn{5}{|c|}{ Dry season 2004} \\
\hline No nitrogen $\left(\mathrm{N}_{1}\right)$ & - & - & - & - \\
\hline Standard rate with 3 splits $\left(\mathrm{N}_{2}\right)$ & 12 & 0.34 & 35 & 44 \\
\hline LCC- based $\mathrm{N}$ management $\left(\mathrm{N}_{3}\right)$ & 18 & 0.47 & 39 & 65 \\
\hline Standard rate with 2 splits $\left(\mathrm{N}_{4}\right)$ & 10 & 0.37 & 27 & 42 \\
\hline $\begin{array}{l}\text { Standard rate with deep } \\
\text { placement \& LCC based }\left(\mathrm{N}_{5}\right)\end{array}$ & 12 & 0.21 & 57 & 44 \\
\hline CV $(\%)$ & 26 & 22 & 17 & 9 \\
\hline LSD & $6 * *$ & $0.13 * *$ & $11 * *$ & $7.0^{* *}$ \\
\hline
\end{tabular}

$\underline{a}=$ significant at $5 \%$ level, $* *=$ significant at $1 \%$ level.

\section{Nitrogen balance in the soil}

Nitrogen balance was estimated for the whole year (wet and dry season rice) and presented as apparent $\mathrm{N}$ balance and actual $\mathrm{N}$ balance (Table 4). The apparent $\mathrm{N}$ balance is the quantity of $\mathrm{N}$ as calculated by deducting the amount of $\mathrm{N}$ removed in grain and straw of the crop from the sum of the amounts of $\mathrm{N}$ present in soil at the beginning of wet season, applied through chemical fertilizer, and added in the 
soil through straw. Actual $\mathrm{N}$ balance refers to the $\mathrm{NH}_{4}{ }^{+}-\mathrm{N}$ and $\mathrm{NO}_{3}{ }^{-}-\mathrm{N}$ content of the soil after harvesting of dry season rice.

Ammonium $\mathrm{N}$ ranged from 4 to $10 \mathrm{~kg} / \mathrm{ha}$ with no significant interaction between seed-drilling pattern and $\mathrm{N}$ management strategies. Non-significant values of $\mathrm{NH}_{4}{ }^{+}-\mathrm{N}$ before rice planting and both $\mathrm{NH}_{4}{ }^{+}-\mathrm{N}$ and $\mathrm{NO}_{3}{ }^{-} \mathrm{N}$ after rice harvest indicate no carry over of fertilizer $\mathrm{N}$. The indigenous soil $\mathrm{NO}_{3}{ }^{-}$(in $\mathrm{N}_{1}$ plot) differed with the in paired-row drill-seeded plots $\left(\mathrm{N}_{2}\right.$ and $\left.\mathrm{N}_{5}\right)$ than $\mathrm{N}$ management strategies. The results likewise show higher in $\mathrm{NO}_{3}{ }^{-}$in paired-row seeded than the single-row seeded plots probably indicating soil heterogeneity in the experimental area which was possibly brought about by the previous experiments conducted in the same area.

Table 3. Nitrogen-use efficiency as affected by interaction effect of drill seeding pattern and management during the wet season 2003.

\begin{tabular}{|c|c|c|c|}
\hline $\begin{array}{l}\text { Drill seeding } \\
\text { pattern }\end{array}$ & $\begin{array}{c}\text { Nitrogen management } \\
\text { strategy }\end{array}$ & $\begin{array}{c}\text { Recovery efficiency } \\
\left(\begin{array}{c}\Delta \mathrm{kg} \mathrm{N} \text { uptake/ } \mathrm{kg} \mathrm{N} \\
\text { applied })\end{array}\right.\end{array}$ & $\begin{array}{c}\text { Physiological } \\
\text { efficiency } \\
(\Delta \mathrm{kg} \text { grain } \\
\left.\Delta \mathrm{kg}^{-1} \mathrm{~N} \text { uptake }\right)\end{array}$ \\
\hline \multirow[t]{5}{*}{ Single row } & No nitrogen $\left(\mathrm{N}_{1}\right)$ & - & - \\
\hline & Standard rate with 3 splits $\left(\mathrm{N}_{2}\right)$ & 0.32 & 59 \\
\hline & LCC- based $\mathrm{N}$ management $\left(\mathrm{N}_{3}\right)$ & 0.32 & 70 \\
\hline & Standard rate with 2 splits $\left(\mathrm{N}_{4}\right)$ & 0.28 & 53 \\
\hline & $\begin{array}{l}\text { Standard rate with deep } \\
\text { placement \& LCC based }\left(\mathrm{N}_{5}\right)\end{array}$ & 0.30 & 62 \\
\hline \multirow[t]{5}{*}{ Paired rows } & No nitrogen $\left(\mathrm{N}_{1}\right)$ & - & - \\
\hline & Standard rate with 3 splits $\left(\mathrm{N}_{2}\right)$ & 0.38 & 53 \\
\hline & LCC- based $\mathrm{N}$ management $\left(\mathrm{N}_{3}\right)$ & 0.43 & 52 \\
\hline & Standard rate with 2 splits $\left(\mathrm{N}_{4}\right)$ & 0.34 & 51 \\
\hline & $\begin{array}{l}\text { Standard rate with deep } \\
\text { placement \& LCC based }\left(\mathrm{N}_{5}\right)\end{array}$ & 0.19 & 67 \\
\hline $\mathrm{CV}(\%)$ & & 19 & 11 \\
\hline LSD & & $0.10^{*}$ & $11^{*}$ \\
\hline
\end{tabular}

al $*=$ significant at $5 \%$ level, $\mathrm{ns}=$ not significant at $5 \%$ level.

Nitrogen in residue ranged from 8 to $18 \mathrm{~kg} / \mathrm{ha}$. Available $\mathrm{N}$ before planting was higher than the actual $\mathrm{N}$ balance indicating the mineralization of organic $\mathrm{N}$ during the turnaround period. Crop removal of $\mathrm{N}$ were statistically significant among the $\mathrm{N}$ management strategies within and across drill-seeding patterns, but comparisons among the four $\mathrm{N}$ management strategies showed that $\mathrm{N}$ removal was lowest in $\mathrm{N}_{5}$. Treatment $\mathrm{N}_{3}$ (paired-row drill seeding) had the highest crop $\mathrm{N}$ removed, which was statistically similar to $\mathrm{N}_{4}, \mathrm{~N}_{3}$, and $\mathrm{N}_{2}$ in single-row seeding and $\mathrm{N}_{2}$ and $\mathrm{N}_{4}$ in paired-row seeding. Significantly lower $\mathrm{N}$ removed in no $\mathrm{N}$ plot $\left(\mathrm{N}_{1}\right)$ in both single-row and paired-row seeded plots. 
Table 4. Apparent and actual $\mathrm{N}$ balance as affected by different drill seeding patterns and $\mathrm{N}$ management strategies during the wet season 2003 and dry season 2004. $\stackrel{a}{-}$

\begin{tabular}{|c|c|c|c|c|c|c|c|c|c|c|}
\hline \multirow[t]{2}{*}{$\begin{array}{l}\text { Drill } \\
\text { seeding } \\
\text { pattern }\end{array}$} & \multirow[t]{2}{*}{$\begin{array}{l}\text { Nitrogen management } \\
\text { strategy }\end{array}$} & \multirow[t]{2}{*}{$\begin{array}{c}\text { Fertilizer } \\
\text { applied } \\
\text { during 2003- } \\
04 \\
\text { (kg/ha) } \\
\text { (A) }\end{array}$} & \multirow[t]{2}{*}{$\begin{array}{c}\mathrm{N} \text { from rice } \\
\text { straw during } \\
\text { wet season } \\
2003 \\
(\mathrm{~kg} / \mathrm{ha}) \\
(\mathrm{B})\end{array}$} & \multicolumn{2}{|c|}{$\begin{array}{c}\text { Available } \\
\mathrm{N} \text { in soil before } \\
\text { wet season } 2003 \\
\text { rice sowing } \\
(\mathrm{kg} / \mathrm{ha}) \\
(\mathrm{C})\end{array}$} & \multirow{2}{*}{$\begin{array}{c}\text { N removed } \\
\text { by rice } \\
\text { during } \\
2003-04 \\
(\mathrm{~kg} / \mathrm{ha}) \\
(\mathrm{D})\end{array}$} & \multicolumn{2}{|c|}{$\begin{array}{c}\text { Available N } \\
\text { left in soil } \\
\text { after dry season } \\
2004 \text { rice harvest } \\
(\mathrm{kg} / \mathrm{ha}) \\
\text { (E) }\end{array}$} & \multirow[t]{2}{*}{$\begin{array}{c}\text { Apparent N } \\
\text { balance } \\
(\mathrm{A}+\mathrm{B}+\mathrm{C})-\mathrm{D} \\
(\mathrm{kg} / \mathrm{ha}) \\
\end{array}$} & \multirow[t]{2}{*}{$\begin{array}{c}\text { Actual N } \\
\text { balance } \\
(\mathrm{kg} / \mathrm{ha})\end{array}$} \\
\hline & & & & $\mathrm{NH}_{4}{ }^{+}-\mathrm{N}$ & $\mathrm{NO}_{3}{ }^{-}-\mathrm{N}$ & & $\mathrm{NH}_{4}{ }^{+}-\mathrm{N}$ & $\mathrm{NO}_{3}^{-}{ }^{-} \mathrm{N}$ & & \\
\hline \multirow{5}{*}{$\begin{array}{l}\text { Single } \\
\text { row }\end{array}$} & No nitrogen $\left(\mathrm{N}_{1}\right)$ & 0 & 8 & 4 & 6 & 96 & 1 & 5 & -78 & 6 \\
\hline & Standard rate with 3 splits $\left(\mathrm{N}_{2}\right)$ & 270 & 16 & 9 & 5 & 189 & 5 & 4 & 111 & 9 \\
\hline & LCC- based $\mathrm{N}$ management $\left(\mathrm{N}_{3}\right)$ & 227 & 13 & 8 & 7 & 182 & 3 & 5 & 73 & 8 \\
\hline & Standard rate with 2 splits $\left(\mathrm{N}_{4}\right)$ & 270 & 15 & 7 & 10 & 197 & 3 & 4 & 105 & 7 \\
\hline & $\begin{array}{l}\text { Standard rate with deep placement \& } \\
\text { LCC based }\left(\mathrm{N}_{5}\right)\end{array}$ & 270 & 16 & 10 & 10 & 166 & 7 & 5 & 140 & 12 \\
\hline \multirow{5}{*}{$\begin{array}{l}\text { Paired } \\
\text { rows }\end{array}$} & No nitrogen $\left(\mathrm{N}_{1}\right)$ & 0 & 7 & 5 & 5 & 90 & 3 & 4 & -73 & 7 \\
\hline & Standard rate with 3 splits $\left(\mathrm{N}_{2}\right)$ & 270 & 18 & 5 & 12 & 180 & 1 & 7 & 125 & 8 \\
\hline & LCC- based $\mathrm{N}$ management $\left(\mathrm{N}_{3}\right)$ & 227 & 16 & 7 & 5 & 198 & 2 & 4 & 57 & 6 \\
\hline & Standard rate with 2 splits $\left(\mathrm{N}_{4}\right)$ & 270 & 15 & 7 & 5 & 175 & 4 & 3 & 122 & 7 \\
\hline & $\begin{array}{l}\text { Standard rate with deep placement \& } \\
\text { LCC based }\left(\mathrm{N}_{5}\right)\end{array}$ & 270 & 11 & 4 & 12 & 140 & 2 & 5 & 157 & 7 \\
\hline $\mathrm{CV}(\%)$ & & & 15 & 49 & 42 & 7.3 & 98 & 43 & & \\
\hline LSD & & & $4^{*}$ & ns & $6^{*}$ & $20 *$ & ns & ns & & \\
\hline
\end{tabular}

$\underline{\mathrm{a}} \mathrm{*}=$ significant at $5 \%$ level, ns $=$ not significant at $5 \%$ level. 
Aggregate residual available $\mathrm{N}$ after harvest ranged from 6 to $12 \mathrm{~kg} / \mathrm{ha}$, the greater bulk $(60 \%)$ of which was in the $\mathrm{NO}_{3}^{-}$form. Differences were not significant indicating that even the plot having no $\mathrm{N}$ fertilizer $\left(\mathrm{N}_{1}\right)$ had the same magnitude of available $\mathrm{N}$ stock for the next crop as the $\mathrm{N}$-fertilized plots. Across various treatments, apparent $\mathrm{N}$ balance ranged from -73 to $157 \mathrm{~kg} / \mathrm{ha}$, which was remarkably higher form the actual $\mathrm{N}$ balance ranging 6-12 kg/ha. Although there was large amount of positive apparent $\mathrm{N}$ balance in $\mathrm{N}$ fertilized plots, these amounts were not available to the succeeding crop due to large losses resulting in a low actual $\mathrm{N}$ balance. Since apparent balance approach did not include the measurements of other components of $\mathrm{N}$ balance ( $\mathrm{N}$ gain from biological nitrogen fixation and $\mathrm{N}$ loss by various mechanisms), this gave erroneous results. This is because of difficulties involved in the measurements of various gains and losses of $\mathrm{N}$. Nonetheless, actual $\mathrm{N}$ balance allows a rough estimate of availability of residual $\mathrm{N}$ supply from fertilizer at the beginning of the crop and, therefore, this along with the assessment of crop $\mathrm{N}$ requirement for a given yield potential can be used for making fertilizer recommendation for succeeding crop.

\section{Conclusion}

Drill seeding pattern did not affect grain yield, the efficiencies of water and $\mathrm{N}$ use and $\mathrm{N}$ balance indicating that both seeding patterns had similar yield potential under dry seeding. Grain yield and $\mathrm{N}$ use efficiency (agronomic and recovery) were higher in the LCC-based $\mathrm{N}$ management $\left(\mathrm{N}_{3}\right)$ than in other strategies despite the lower $\mathrm{N}$ input suggesting useful uses of LCC for $\mathrm{N}$ management in DSR. Actual $\mathrm{N}$ balance across drill seeding pattern and $\mathrm{N}$ management during the two seasons ranged from $6-12 \mathrm{~kg} / \mathrm{ha}$, while apparent $\mathrm{N}$ balance ranged from 57-157 $\mathrm{kg} / \mathrm{ha}$. Although there was large amount of positive apparent $\mathrm{N}$ balance in $\mathrm{N}$ fertilized plots, these amounts were not available to the succeeding crop due to large losses resulting in a low actual $\mathrm{N}$ balance. A fertilizer recommendation should be based on the actual $\mathrm{N}$ balance along with the assessment of crop $\mathrm{N}$ requirement for a given yield potential for succeeding crop.

\section{References}

Bakker, R.R., M. A. Bell, and J.F. Rickman. 2002. Mechanization issues in tillage and crop establishment for dry direct-seeded rice. In: Pandey, S., M. Motimar, L. Wade, T.P. Toung, K. Lopez and B. Hardy (ed.) 2002. Direct seeding: research issues and opportunities. Proceedings of the International Workshop on Direct Seeding in Asian Rice Systems: Strategic Issues and Opportunities, 25-28 January 2000, Bangkok, Thailand. Los Baños, (Philippines): International Rice Research Institute. 219 P.

Balasubramanian, V., J.K. Ladha, R.K. Gupta, R.K. Naresh, R.S. Mehla, Bijay-Singh, and Yadvinder-Singh. 2003. Technology options for rice in the rice-wheat system in South Asia. p. 115-147. In J.K. Ladha et al. (ed.) Improving the productivity and 
sustainability of rice-wheat systems: Issues and impact. ASA Spec. Publ. 65. ASA, CSSA, and SSSA, Madison, WI.

Balasubramanian, V., A. C. Morales, R. T. Cruz, N.N.DE, P.S. Tan and Z. Zaini. 2000. Leaf colur chart as a simple decision tool for N management in lowland rice. P. 278. In 2000 Annual Meetings Abstr. ASA-CSSA-SSSA, Madison, WI.

Bhushan L, J. K. Ladha, R. K. Gupta, S. Singh, A. Tirol-Padre, Y.S. Saharawat, M. Gathala, H. Pathak. 2007. Saving of water and labor in rice-wheat system with notillage and direct-seeding technologies. Agronomy J. 99: 1288-1296.

Buresh, R. J., S. Peng, C. Witt, V. Balasubramanian and E. Laureles. 2001. Improving nitrogen fertilizer-use efficiency for rice: How does management option compare? In 2001 ASA-CSSA-SSSA Meeting Abstr. Charlotte, NC. 21-25 Oct. 2001.

Devnani, R. S. 2002. Direct seeding options, equipment development and their performance on yield of rice crop. Agricultural Mechanization in Asia, Africa and Latin America 33(4):27-33.

Dorich, R. A. and D. W. Nelson. 1984. Evaluation of manual cadmium reduction methods for determination of nitrate in potassium chloride extracts of soil. Soil Sci. Soc. Am. J. 48:72-75.

Ho, Nai-Kin and Z. Romli. 2002. Impact of direct seeding on rice cultivation: lessons from the Muda area of Malaysia. In: Pandey, S., M. Motimar, L. Wade, T.P. Toung, K. Lopez and B. Hardy (ed.) 2002. Direct seeding: research issues and opportunities. Proceedings of the International Workshop on Direct Seeding in Asian Rice Systems: Strategic Issues and Opportunities, 25-28 January 2000, Bangkok, Thailand. Los Baños, (Philippines): International Rice Research Institute. 383 P.

Jackson, W. A., C. E. Frost and D. M. Hildreth. 1975. Versatile multirange analytical manifold for automated analysis of nitrate nitrogen. Soil Sci. Soc. Am. Proc. 33: 502593

Keeny, D.R. and D.W. Nelson. 1982. Nitrogen inorganic forms. In: Page, A. L., R.H. Miller and D.R. Keeney (eds.) Methods of soil analysis part 2- chemical and microbiological properties. ASA, SSSA, Madison, WI. USA.

Kempers, T. 1986. Ammonium determination in soil extracts by salicylate method. Commu. Soil Sci. Anal. 17:715-723.

Ladha J. K., H. P. Pathak, T. J. Krupnik, J. Six and C.Van Kessel 2005. Efficiency of fertilizer nitrogen in cereal production: retrospect and prospect. Advances in Agronomy 87: 86-156.

Linwattana, G. 2001. Nitrogen management for direct seeded rice (Oryza sativa L.) in drought-prone lowlands of Ubon Ratchathani, Thailand. $\mathrm{Ph} \mathrm{D}$ Dissertation. University of the Philippines Los Baños, Philippines.

Pandey, S. and L. Velasco. 2002. Economics of direct seeding in Asia: patterns of adoption and research priorities. In : Pandey, S., M. Motimar, L. Wade, T. P. Toung, K. Lopez and B. Hardy (eds.) 2002. Direct seeding: research issues and 
opportunities. Proceedings of the International Workshop on Direct Seeding in Asian Rice Systems: Strategic Issues and Opportunities, 25-28 January 2000, Bangkok, Thailand. Los Baños, (Philippines): International Rice Research Institute. P 383.

Yamauchi, M., D. V. Aragones, P. R. Casayuran, P. C. Sta. Cruz, C. A. Asis, J. R. and R. T. Cruz. 2000. Seedling establishment and grain yield of tropical rice sown in puddle soil. Agron. J. 92: 275-282.

Yoshida, S. 1976. Laboratory manual for physiological study of rice. $3^{\text {rd }}$ edition. P. 27. IRRI. PO Box 933, Manila, Philippines. 